\title{
DIMENSIONS OF EQUALITY: DOCTRINES OF LIMITATION
}

\author{
Drew S. Days III*
}

INTRODUCTION

America can be justifiably proud of the enormous strides its legal system has made since the end of World War II in identifying and vindicating equality rights under the U.S. Constitution. The 1954 decision in Brown v. Board of Education, ' striking down the separate-but-equal doctrine in public education, provided the inspiration and the doctrinal basis ${ }^{2}$ for racial minorities, women, aliens, children born out of wedlock, the disabled, and the poor to pursue their claims for evenhanded treatment in the courts. ${ }^{3}$ We also have seen greater judicial protection of equality in the exercise of rights guaranteed by the first amendment to the Constitution, such as freedom of religion, speech, and the press. ${ }^{4}$ For all this progress, however, the Supreme Court has over the last two decades embraced "doctrines of limitation" that severely constrain the ability of equality claims to get a judicial hearing and to receive vindication. These doctrines raise serious questions as to whether the federal court system can be looked to in the future for meaningful protection of equality rights. It is to a brief discussion of a few of these doctrines-state action, discriminatory intent, and federalism-that I would like to turn.

Copyright $\odot 1992$ by Law and Contemporary Problems

* Alfred M. Rankin Professor of Law, Yale Law School.

I want to thank Paul Sonn for his research assistance in preparing this article.

1. 347 US 483 (1954).

2. The principle that racial classifications are inherently suspect and so warrant the strictest constitutional scrutiny had, of course, been articulated prior to Brown. See United States $v$ Carolene Products Co., 304 US 144, 152 n4 (1938); Korematsu $v$ United States, 323 US 214 (1944). It was only in Brown, however, that the promise of footnote four was realized in a decision invalidating stateimposed racial segregation. See generally Gerald Gunther, Constitutional Law 622-42 (Foundation Press, 11 th ed 1985).

3. See White $v$ Register, 412 US 755 (1973) (reapportionment plan adversely affecting voting rights of African-Americans and Mexican-Americans); Frontiero v Richardson, 411 US 677 (1973) (job benefits disfavoring women employees); Bernal v Fainter, 467 US 216 (1984) (alienage/citizenship requirements to become a notary); Trimble $v$ Gordon, 430 US 762 (1977) (inheritance rights of illegitimate children); City of Cleburne, Texas v Cleburne Living Center, 473 US 432 (1985) (zoning ordinance excluding group home for mentally retarded); Harper v Virginia Bd. of Elections, 383 US 663 (1966) (poll tax that disenfranchised the poor).

4. See Widmar v Vincent, 454 US 263 (1981) (religion); Police Department of Chicago v Mosely, 408 US 92 (1972) (speech); Minneapolis Star E Tribune Co. v Minnesota Comm'r of Rev., 460 US 575 (1983) (press). 


\section{Governmental or State Action}

\section{A. State Action}

The first doctrine of limitation is that of governmental or state action. By reading beyond the Preamble to the Constitution, one learns that both the protections enumerated in the Bill of Rights and the bar against denial of the equal protection of the laws in the fourteenth amendment are directed at limiting governmental, not private, action. Moreover, it should be apparent that without the recognition of a distinction between the public and private spheres in our society, equally important personal rights, such as the right to equal protection and the freedom of intimate association, would be brought frequently and unavoidably into conflict. Failure to recognize separate public and private spheres would also undermine the fundamental distinction drawn between government activity and private enterprise in our capitalist economy.

Concerns about the severe limitations that the governmental action doctrine imposes upon claims of equality do not stem from a desire to bring those conflicts about. Rather, they arise for three other reasons. First, the Supreme Court has adopted an increasingly narrow definition of what constitutes governmental action. Second, the Court has continued to leave ambiguous Congress's ability to reach nongovernmental denials of equal treatment under section 5 of the fourteenth amendment. Third, the Court has brought a troubling flexibility in recent years to its definition of the term "state" in the fourteenth amendment.

1. Government-Private Enterprise Interdependence. It is theoretically possible to identify polar situations where one can say with confidence that only private behavior is involved or that governmental action is clearly present. But it is difficult to locate on the continuum between the two poles where the equal protection clause should have no bearing and where the clause ought to have force. In our highly complex society, business enterprises that would surely have been viewed at an earlier time in our history as quintessentially private are now heavily regulated by government. Government has also looked increasingly to private entities to perform public functions that it might have to discharge otherwise. ${ }^{5}$ This interdependency should make their actions prime candidates for equal protection analysis.

However, the Court has gradually, but firmly, moved away from precedents developed beginning in the $1950 \mathrm{~s}$ that placed great significance upon the fact of government-private enterprise interdependence. ${ }^{6}$ The values

5. See, for example, Jackson v Metropolitan Edison Co., 419 US 345 (1974) (provision of electric power by privately owned but highly regulated utility not viewed as state action).

6. Cases such as Burton v Wilmington Parking Authority, 365 US 715 (1961), and Reitman v Mulkey, 387 US 369 (1967), represent the high-water mark of state action doctrine. Beginning with Moose Lodge $v$ Irvis, 407 US 163 (1972), the Supreme Court over the course of the 1970s and 1980s retreated from Reitman's expansive view of state action. Recently, however, there has been a curious resurgence of state action doctrine in cases concerning the applicability of constitutional limits to the 
underlying the Court's inclination to draw the line in a way that insulates denials of equality from constitutional scrutiny have not been made entirely clear. ${ }^{7}$ But there seems to be at least an implicit belief that the free enterprise system would be put at risk by a contrary ruling ${ }^{8}$

2. Courts and Private Disputes. One exercise in line-drawing that the Court had to confront in the late 1940s was whether private action must pass constitutional muster when an individual invokes the state's judicial machinery to resolve a private dispute. In a still much-debated ruling, ${ }^{9}$ the Court held that a state court's enforcement of a restrictive covenant agreement between private parties added state action to racial discrimination in violation of the equal protection clause, even though the discriminatory agreement itself was not prohibited by the fourteenth amendment. ${ }^{10}$ That decision raised questions about, among other things, whether the Court's view of governmental action would work against the willingness of private parties to resolve their differences in court rather than to resort to what might be socially unacceptable self-help.

Many thought that further guidance on the scope of this view of governmental action would be forthcoming from the Court's review of criminal trespass convictions of civil rights sit-in demonstrators in the 1960 s. ${ }^{11}$ At issue was whether enforcement by local police of racially discriminatory practices by privately owned places of public accommodation constituted an equal protection violation. In other words, did the government become a partner in the discriminatory acts? As a consequence of certain changes in state law and passage of the public accommodations provisions of the Federal Civil Rights Act of $1964,{ }^{12}$ however, the central constitutional question was left unanswered. As a result, no resolution was reached with respect to what values should determine the location of the governmental

use of peremptory challenges in jury selection. See Edmonson v Leesville Concrete Co., 111 S Ct 2077 (1991) (use of peremptory challenge to remove jury candidates by private civil litigant constitutes state action and so may not be exercised in discriminatory fashion); Georgia v McCollum, $261 \mathrm{Ga} 473$, 405 SE2d 688 (discriminatory use of peremptory challenge by criminal defendant permitted), cert granted, 112 S Ct 370 (1991).

7. See, for example, San Francisco Arts E Athletics, Inc. $v$ US Olympic Committee, 483 US 522, 54247 (1987) (no governmental action in special congressional grant of expansive trademark protection and partial funding); id at 548-60 (Brennan dissenting).

8. See generally Symposium, The Public/Private Distinction, 130 U Pa L Rev 1289 (1982).

9. Shelley $v$ Kraemer, 334 US 1 (1948).

10. For sources on the scholarly debate over the correctness of Shelley, see Herbert Wechsler, Toward Neutral Principles of Constitutional Law, 73 Harv L Rev 1, 29-31 (1959); Louis H. Pollak, Racial Discrimination and Judicial Integrity: A Reply to Professor Wechsler, 108 U Pa L Rev 1, 6 (1959); Louis Henkin, Shelley v Kraemer: Notes for a Revised Opinion, 110 U Pa L Rev 473 (1962).

11. Bell $v$ Maryland, 378 US 226 (1964). Justice Douglas's opinion, while concurring in the dismissal of the trespass charges in Bell, confronted the state action problem head-on, urging that the Court reach the merits and, applying Shelley's logic, dismiss the indictments. Id at 252-60. However, Justice Brennan's Opinion of the Court went to great lengths to duck the issue. Id at 241-42. See Drew S. Days III, Justice William O. Douglas and Civil Rights, in Stephen L. Wasby, ed, He Shall Not Pass This Way Again: The Legacy of Justice William O. Douglas 109, $112-13$ (U Pittsburgh for William O. Douglas Inst, 1990).

12. Title II, 42 USC $\S \S 2000$ a to $2000 a-6$ (1988). See Heart of Allanta Motel, Inc. v United States, 379 US 241 (1964) (sustaining constitutionality of Title II). 
action line in this situation. In subsequent cases involving various forms of licensing or regulation, the Court has generally not found the requisite level of state involvement. ${ }^{13}$

\section{B. Reach of the Enabling Clause}

Questions about the ability of Congress to reach private action through section 5, the enabling clause, of the fourteenth amendment have been with us since 1883. In that year, the Supreme Court declared unconstitutional the Civil Rights Act of 1875, which prohibited, among other things, racial discrimination in places of public accommodation. ${ }^{14}$ It determined that Congress's power to legislate pursuant to section $\mathbf{5}$ was limited to addressing only governmental, not private, racial discrimination. The Court's conclusion in this regard was not preordained, to say the least. ${ }^{15}$ Nevertheless, this narrow view of section 5 has constrained Congress to invoke other sources of authority, in addition to section 5, to legislate against private acts of discrimination, and the Court has not seen fit to question seriously the narrow view's continued vitality. Consequently, when enacting the public accommodations provisions of the Civil Rights Act of 1964, Congress took great pains to invoke its commerce power, as well as section 5 , as authority. ${ }^{16}$ In a challenge to the constitutionality of those provisions, the Court found the commerce power authority sufficient and declined to reach the section 5 question. ${ }^{17}$

\section{Partitioned Concept of State}

One would think that few difficulties of line-drawing would arise where governmental action was found. However, the Court has defined the term "state," as it is used in the fourteenth amendment, in a way that makes application of the equal protection doctrine less than straightforward. In 1974 , for example, the Court held that lower courts erred in ordering a school desegregation plan that encompassed Detroit and a number of its adjoining suburbs. ${ }^{18}$ The record of action by state authorities to create and perpetuate

13. See, for example, Blum v Yaretsky, 457 US 991 (1982); Moose Lodge v. Irvis, 407 US 163 (1972). Moose Lodge held that a racially discriminatory private club's exercise of a state-granted liquor license did not constitute state action sufficient to subject the club's activities to constitutional limitations. Id at 177 . In a secondary holding, the Moose Lodge Court ruled that a Pennsylvania regulation requiring private clubs to abide by their own internal rules constituted state action and so would be unconstitutional insofar as the internal rules sought to be so enforced were themselves discriminatory. Id at 177-79. However, there are no reported post-Moose Lodge cases involving such state attempts to enforce discriminatory club rules.

14. Civil Rights Cases, 109 US 3 (1883).

15. See, for example, United States $v$ Guest, 383 US 745 (1966), where six justices concluded, in separate opinions by Justices Clark at 762 and Brennan at 782 not attracting a majority, that $\$ 5$ empowered Congress to reach purely private conspiracies to interfere with the exercise of 14th amendment rights; Lawrence Tribe, American Constitutional Law 350-53 (Foundation Press, 2d ed 1988).

16. 42 USC $\S \S 2000$ a et seq. See also Gunther, Constitutional Law at 158-64 (cited in note 2) (excerpts of Senate hearings).

17. Heart of Atlanta Motel, 379 US 241.

18. Milliken $v$ Bradley, 418 US 717 (1974). 
racial segregation in Detroit was clear. But the Court decreed that the surrounding suburbs could not be included in a plan to remedy the state's fourteenth amendment violation unless it could be shown that the suburbs themselves engaged in segregative acts that affected the racial composition of Detroit schools. Although for many other legal and constitutional purposes municipalities are mere creatures of the state, the Court concluded that a tradition of local school district autonomy required them to be treated as independent actors. Under this compartmentalized view of state action, violations of constitutional rights may go effectively unremedied. ${ }^{19}$

\section{III}

\section{Purpose or InTent to Discriminate}

\section{A. Intent Becomes an Indispensable Element}

The second limiting doctrine requires that there be, in addition to the presence of a governmental or state actor, a purpose or intent to deny equal protection of the laws. It was not until 1976, in a challenge to a police department employment testing program on the ground that it was racially discriminatory, that the Supreme Court held explicitly that purpose or intent to discriminate was an indispensable element of a constitutional case. ${ }^{20}$ The form of the announcement was rather matter of fact. In truth, however, lower federal courts had decided numerous cases premised on their implicit understanding that certain types of harmful governmental action violated the Constitution, whether intended or not. ${ }^{21} \mathrm{~A}$ contributing factor to what the Court described as a misunderstanding by lower courts of its precedents was that many of its prior decisions had dealt with overt racial classifications. Hence, there had been no need to address the question of what standard would be required in other contexts.

Not surprisingly, given the difficulty of establishing the intent of just one person, this requirement has proven to be a formidable obstacle in redressing governmental conduct that results in inequality along the lines of race, gender, economic status, ${ }^{22}$ class, or other grounds. When confronted with

19. For a discussion of this phenomenon, see Drew S. Days III, School Desegregation Law in the 1980's: Why Isn't Anybody Laughing?, 95 Yale L J 1737, 1753-64 (1986) (book review).

20. Washington v Davis, 426 US 229, 239 (1976). The intent standard does not pertain, however, to statutory claims brought under Title VII of the 1964 Civil Rights Act. 42 USC $\S \S 2000$ e et seq (1988). See Griggs v Duke Power Co., 401 US 424, 432 (1971). In response to what Congress felt was a retrenchment by the Supreme Court with respect to Griggs in Wards Cove v Atonio, 490 US 642 (1989), it recently amended Title VII to codify the Griggs standard. See Civil Rights Act of 1991, Pub L No 102-166, 105 Stat 1071 (1991), to be codified in part at 42 USC $\$ \$ 2000$ e et seq.

21. See Washington v Davis, 426 US at $244 \mathrm{n} 12$ (gathering cases).

22. Even if Washington $v$ Davis were reversed, there would still exist other significant obstacles to an equal protection challenge to economic discrimination. Chief among these is the fact that economic discrimination is subject only to rational basis review under the equal protection clause. See Jefferson v Hackney, 406 US 535, 546 (1972); see also James v Valtierra, 402 US 137 (1971). More recent cases, however, evince a willingness by the Supreme Court to engage at times in a more searching variant of rationality review. See City of Cleburne, Texas v. Cleburne Living Center, 473 US 432 , 447-50 (1985). This type of heightened scrutiny would be particularly appropriate where the challenged practice causes a disproportionate adverse impact to racial minorities. 
the task of establishing requisite discriminatory intent behind the actions over many years of numerous government actors, the burden quickly becomes impossible to bear. ${ }^{23}$

Clearly, in view of the stratification of American society along economic and racial lines, government programs might be expected inevitably to have some disparate impact. There is reason to be concerned, therefore, about a rule that would take such disparate or disproportionate impact as conclusive evidence of a constitutional violation. But no one has argued seriously for such an approach. Even requiring government to provide a federal court with satisfactory explanations for every policy having a disparate impact would be difficult to defend. On the other hand, the current requirement that discriminatory intent be shown means that the courts must accord extraordinary deference to government programs and policies that produce particularly severe consequences for some of the least fortunate and most defenseless groups in society with respect to things that really matter: food, housing, health care, and education.

Were America a country without a shameful history of overt, systematic discrimination against some of these same groups, we might be justified in resisting any call for government to explain itself. Since that is not the case, asking government to defend its policies, including its decision to reject more evenhanded and equally effective measures, accords more with the spirit of the equal protection clause than does the current rule. Such an approach would not mean that the courts would necessarily reject the government's policy decisions, just that reasons would have to be given.

A 1987 decision by the Court underscores the importance of the intent requirement as a "doctrine of limitation." 24 A black man, convicted of murder and sentenced to death for killing a white person, established statistically that black defendants who kill white victims have a significantly greater likelihood of being sentenced to death than either white defendants who kill white victims or defendants of either race who kill blacks. The Supreme Court rejected his claim that the statistics raised valid equal

23. For example, in Mobile v Bolden, 446 US 55, 68-70 (1980), the Supreme Court held that a showing of discriminatory intent was necessary to establish unconstitutional vote dilution. Although on remand the Bolden plaintiffs ultimately succeeded in demonstrating the requisite discriminatory intent, the expenses incurred in making that showing were extraordinary. As a consequence of the intent requirement, only persons with access to substantial financial and institutional resources could hope to win vindication of their constitutional rights. See generally Peyton McCrary, History in the Courts: The Significance of Bolden v. The City of Mobile, in Chandler Davidson, ed, Minority Vote Dilution 47, 59 (Howard U Press, 1984).

Ironically, just shortly after Congress had acted to restore the effects test through a statutory prohibition, 1982 Voting Rights Amendments, Pub L No 97-205, § 3, 96 Stat 131 (1982), codified at 42 USC $\S \S 1971,1973$ to $1973 \mathrm{aa}-6(1988)$, the Court found in another case of alleged racially discriminatory redistricting that the Bolden test can indeed be satisfied by inferring the requisite intent from discriminatory effects. See Rogers $v$ Lodge, 458 US 613, 623-24 (1982).

McCleskey $v \operatorname{Kemp}, 481$ US 279 (1987), established a similarly prohibitive burden for prisoner challenges to the racist manner in which prosecutorial systems are administered in many jurisdictions. See notes 24-26 and accompanying text; see also Randall L. Kennedy, McCleskey v. Kemp: Race, Capital Punishment, and the Supreme Court, 101 Harv L Rev 1388 (1988).

24. McCleskey, 481 US 279. 
protection issues because he was unable to establish that the pattern was intentional. ${ }^{25}$ The state was spared, consequently, the burden of explaining its reasons for operating a criminal justice system that produced such racially skewed results. Against Georgia's undeniable history of overt, explicit discrimination against African-Americans, ${ }^{26}$ it is difficult to square the Court's results with one of the central purposes the equal protection clause was designed to serve, namely, the shielding of blacks from hostile, racially motivated governmental practices.

\section{B. "Invidious" Not "But-For" Intent}

The foregoing description suggests that the equal protection claimant has carried his or her evidentiary burden once intent to discriminate has been established. That assumption would be incorrect, for there are, in the Supreme Court's view, degrees of intent. Unlike the familiar rule of tort lawthat one is presumed to have intended the natural and foreseeable consequences of one's, acts-under our constitutional doctrine, the government is not necessarily liable for the natural and foreseeable consequences of its acts.

According to the Court, where government pursues a legitimate goal of assisting one group, even if the natural and foreseeable consequence is to disadvantage another, the requisite intent upon which to base an equal protection claim is not present. Captured in the phrases "but for" "and "in spite of," discriminatory intent is present where government would not have pursued a particular course of conduct "but for" its knowledge of the disparate consequences; acting to achieve other legitimate ends "in spite of" knowledge of collateral disproportionate impact does not demonstrate the required invidious intent. Faithful to this standard, the Court concluded that a Massachusetts veterans' preference law with an especially disproportionate impact upon women passed constitutional muster, even though the consequences were foreseeable to the legislature and alternative ways of assisting veterans with less disparate impact were available. ${ }^{27} \mathrm{Here}$, as in the Georgia death penalty case, the Court embraced a categorical rule in the face of reasons to wonder whether the Massachusetts policy was not another manifestation of group antagonism, in this case outmoded views of the role of women in society. ${ }^{28}$

25. Id at 298-99.

26. See Arnold Barnett, Some Distribution Patterns for the Georgia Death Sentence, 18 UC Davis L Rev 1327 (1985); David C. Baldus, George Woodworth, \& Charles A. Pulaski, Jr., Monitoring and Evaluating Contemporary Death Sentencing Systems: Lessons from Georgia, 18 UC Davis L Rev 1375 (1985); Jack Greenberg, Race Relations and American Law (Columbia U Press, 1959).

27. Personnel Administrator of Massachusetts y Feeney, 442 US 256 (1979). A variety of less discriminatory alternatives was outlined in John H. Fleming \& Charles A. Shanor, Veterans 'Preferences in Public Employment: Unconstitutional Gender Discrimination?, 26 Emory L J 13, $50-52$ (1977).

28. Such bias is evidenced, among other places, in the fact that until 1971 the Massachusetts statute and implementing regulations exempted from the preference job categories "especially calling for women." See Feeney, 442 US at 284-85 (Marshall dissenting). 


\section{IV}

\section{Federalism}

The third and final doctrine I want to discuss is federalism. America fought a Civil War over slavery and the future of the Union. In its aftermath, three amendments were added to the Constitution, and Congress enacted numerous statutes designed to enforce the protections of individual rights guaranteed by those amendments. ${ }^{29}$ For the first time in our history, the states found themselves subject to constraints upon their treatment of persons within their jurisdiction like those that the Bill of Rights already had imposed upon the federal government. ${ }^{30}$ Additionally, federal courts were given plenary jurisdiction for the first time to entertain cases and controversies arising under the Constitution, laws, and treaties of the United States. ${ }^{31}$

\section{A. Privileges and Immunities Clause}

The Reconstruction era produced a new order among the federal government, the several states, and the people. That new order was designed to place the federal government in a special role of ensuring that citizens of the United States enjoyed equal status free from attempts by the states to dictate otherwise. One textual basis for that view was the privileges and immunities clause which precedes the equal protection clause in the fourteenth amendment. It reads: "No State shall make or enforce any law which shall abridge the privileges or immunities of citizens of the United States." 32 It offered at least the possibility that certain rights that civilized and democratic societies had come to associate with citizenship would be available uniformly throughout the land.

Had this reading been adopted by the Court, much of the law laboriously and belatedly developed under the equal protection clause of the same amendment might have been unnecessary. Unfortunately, in its earliest construction of the Civil War amendments, ${ }^{33}$ the Court reduced the privileges

29. In brief, the 13th amendment (1865) emancipated black slaves, the 14th amendment (1868) granted them citizenship, and the 15th amendment (1870) prohibited discrimination against the newly freed slaves on the basis of race or previous enslavement. During the period between 1866 and 1875 , Congress enacted a number of statutes aimed at implementing these amendments, the most important of which are now codified at 42 USC $\S \S 1981,1982,1983$, and 1985.

30. For a summary of the federal legislation policy for this period, see Mitchum $v$ Foster, 407 US 225, 238-44 (1972).

31. Act of March 3, 1875, § 1, ch 137, 18 (part 3) Stat 470 (1875) (granting original cognizance, concurrent with the courts of the several states, of all civil suits, where the matter in dispute exceeds five hundred dollars "and arises under the Constitution or laws of the United States, or treaties made, or which shall be made, under their authority. ..."). Federal question jurisdiction is currently codified at 28 USC $\$ 1331$ (1988) and no longer requires a minimum amount in controversy.

Federal jurisdiction to enjoin unconstitutional state court proceedings was also conferred at this time by 42 USC $\$ 1983$, which was interpreted as falling under the statutory exception to the AntiInjunction Act, 28 USC $\$ 2283$ (1988). The Anti-Injunction Act otherwise imposes a blanket prohibition against such suits. See Mitchum v Foster, 407 US at 242-43.

32. US Const, Amend XIV, $\S 1, \mathrm{cl} 2$.

33. Slaughterhouse Cases, 83 US 36,75 (1872). 
and immunities clause to a redundancy, finding that no greater role was envisioned for the federal government than already existed under a similar provision in Article IV of the Constitution. ${ }^{34}$ That role, said the Court, was to ensure that states did not interfere with the special relationship citizens had with the federal government, such as the right to vote in federal elections.

The status of the privileges and immunities clause of the fourteenth amendment has remained essentially unaltered since the early 1870s. One would be justified in concluding that this is so because the Court continues to embrace a view of federalism that minimizes the transformative effect that the Civil War amendments were designed to produce in the pre-war relationship between the federal government and the states.

\section{B. Eleventh Amendment}

In sharp contrast to the Court's unwillingness to read anything meaningful in the language of the privileges and immunities clause, it has given the eleventh amendment increasingly broad interpretations that find no basis in its actual wording. That amendment imposes limits on federal court jurisdiction to entertain certain types of suits brought against states. For example, it prohibits suits against states by citizens of another state. It has been read by the Court, however, to preclude suits in federal courts brought against states by their own citizens. ${ }^{35}$

Recognizing the difficulty of interpreting the eleventh amendment in a way that would bar suits in federal courts under the equal prorection clause, the prohibitions of which speak explicitly to the states, the Court has constructed an elaborate set of doctrines to avoid that anomaly. ${ }^{36}$ Nevertheless, the eleventh amendment continues to be an obstacle to effective prosecution of equal protection claims in federal court, particularly with respect to retrospective relief. Though the Court has acknowledged recently Congress's power to enact legislative overrides of the eleventh amendment bar, ${ }^{37}$ every day of delay before all federal laws are revised to show an intent to override the bar to suit means that some meritorious claims of equal protection denial will be extinguished.

34. US Const, Art IV, § 2 .

35. Hans v Louisiana, 134 US 1 (1890). See also Pennhurst State School \& Hosp. v Halderman (Pennhurst II), 465 US 89, 121 (1984) (federal courts exercising pendent jurisdiction may not enforce state law claims against state defendants); Atascadero State Hospital v Scanlon, 473 US 234, 242 (1985) (congressional intent to abrogate statutorily states' 11 th amendment immunity from suit must be stated explicitly). But see Fitzpatrick $v$ Bitzer, 427 US 445, 456 (1976) (finding congressional intent to abrogate $1 \mathrm{lth}$ amendment immunity under Title VII and noting that the 11 th amendment is less of a hurdle for legislation passed pursuant to $\$ 5$ of the 14 th amendment); Pennsylvania v Union Gas Co., 491 US 1 (1989) (same under CERCLA).

36. See, for example, the doctrine announced in Ex Parle Young, 209 US 123 (1908), which allows suits for equitable relief against state officers for unconstitutional conduct. See also Edelman "Jorda". 415 US 651, 664 (1974) (though 1 lth amendment bars retrospective compensation for damages, prospective injunctive relief against states is available); Monell v Department of Social Serrices of lieze lork City, 436 US 658, $690 \mathrm{n} 54$ (1978) (political subdivisions of states such as counties, municipalities, and school boards not protected by $1 \mathrm{lth}$ amendment).

37. Pennsyluania "' Inion Gas Co. . 491 US 1, 13-17 (1989). 


\section{Conclusion}

One should not come away from my recitation despondent over the state of equal protection guarantees under the Constitution. Cases are won every day, and rights are vindicated. But we should keep in mind, first, that the doctrines I have described above are serious barriers to obtaining redress for equality violations; and, second, that these doctrines need not last forever, but represent, rather, only choices among competing alternatives. Some of the alternatives not chosen appear more deserving of the Court's endorsement than the doctrines now in place. These alternative interpretations may one day prove persuasive to a majority of the Court. 